\title{
Determination of Boiler Building Verticality in Power Plant Construction using Terrestrial Laser Scanner (TLS)
}

\author{
Mohamad Bagas Setiawan¹, Yulaikhah², Ruli Andaru² \\ ${ }^{1}$ Alumni Departemen Teknik Geodesi FT-UGM, Indonesia \\ 2 Staf Pengajar Departemen Teknik Geodesi FT-UGM, Indonesia
}

\section{Article History: \\ Received 12 November 2018 \\ Received in revised form 6 June 2019 \\ Accepted 11 June 2019 \\ Available online 28 June 2019}

\section{Keywords: \\ terrestrial laser scanner, tingkat verticality, konstruksi boiler, toleransi verticality, PLTU}

Corresponding Author:

Mohamad Bagas Setiawan

Email: mohamad.bagas.st@gmail.com

\begin{abstract}
Nowadays, Indonesian government is focusing on build up infrastructures, especially power plant to fulfil electrical energy needs. One of the power plants that will be built up is Waai power plant which located on Waai Village, Maluku Province. Waai power plant had been postponed since 2014. In order to build this power plant, the advisability of the building needed to be checked from its verticality level. This level was determined by Terrestrial Laser Scanner (TLS). The TLS's point clouds were registered using two methods, there are target to target and cloud to cloud methods. There are 65 beams on the power plant boiler building, but only 31 beams that used as the samples to assign the verticality of the boiler construction. The verticality level was set on the $X$ axis, $Y$-axis, and the resultant of the $X$ and $Y$ axis by using Pythagoras theorem after the bottom and top coordinates from each beam was determined. The Queensland Building and Construction Admission Standards and Tolerances Guide 2016 was used as tolerance of verticality level. The result of the verticality calculation presented on the X-axis consisted from - $0^{\circ} 1^{\prime} 26,678^{\prime \prime}$ to $0^{\circ} 4^{\prime} 11,778^{\prime \prime}$ with the average was $0^{\circ} 1^{\prime} 40,820^{\prime \prime}$ and major direction pointed the positive axis. On the Y-axis, the average was $-0^{\circ} 0^{\prime} 45,772$ " with $-0^{\circ} 3^{\prime} 33,345^{\prime \prime}$ as minimum and $0^{\circ} 1^{\prime} 25,319^{\prime \prime}$ as the maximum and the major direction went to the negative axis. The verticality on the resultant of $X$ and $Y$ axis was from $0^{\circ} 0^{\prime} 45,225^{\prime \prime}$ until $0^{\circ} 4^{\prime}$ $15,674^{\prime \prime}$ with the average was $0^{\circ} 2^{\prime} 27,057^{\prime \prime}$ and the direction was to the southeast. After the verticality number was compared with the tolerance, the verticality level was smaller than the standard on each beam. The conclusion is the boiler building on the Waai power plant can be categorized safe to reconstruct.
\end{abstract}

(C) Author(s) 2019. This is an open access article under the Creative Commons Attribution-ShareAlike 4.0 International License (CC BY-SA 4.0).

\section{Pendahuluan}

Dalam rangka melaksanakan kebijakan listrik 35000 mega-watt dalam kurun waktu 5 tahun (Biro Perencanaan dan Kerja Sama Mineral Kementerian Energi dan Sumber Daya, 2015), pemerintah melakukan pembangunan pembangkit listrik. Salah satu pembangkit listrik yang akan dibangun kembali setelah lama mangkrak terhitung dari tahun 2014 adalah PLTU di Desa Waai, Salahutu, Maluku Tengah. Oleh karena itu, pemeriksaan kelayakan bangunan perlu dilakukan dengan menentukan tingkat verticality bangunan tersebut.

Pendeteksian tingkat verticality bangunan biasanya ditentukan dengan Total Station (TS), Global Positioning
System (GPS), dan akselerometer. Namun saat ini, Terrestrial Laser Scanner (TLS) berkembang dengan prinsip kerja penginderaan jauh untuk memperoleh data berupa point cloud yang dapat digunakan pula dalam pendeteksian tingkat verticality. Data yang diperoleh dari pengukuran TLS lebih detail jika dibandingkan dengan metode lain. Terrestrial Laser Scanner (TLS) merupakan suatu sistem penginderaan jauh untuk menentukan jarak suatu objek dengan menganalisis pantulan sinar laser yang mengenai permukaan suatu objek (Soudarissanane, 2016). TLS dapat digunakan untuk mendeteksi tingkat verticality bangunan (Kregar, dkk., 2015). Selain itu, pengukuran dengan TLS dapat dilakukan dalam waktu yang relatif lebih cepat jika dibandingkan 
dengan metode lain (Kregar, dkk., 2015). Keunggulan pengukuran dengan TLS yaitu data point cloud yang diperoleh dapat untuk membentuk model 3D dari bangunan yang diukur.

Paper ini menentukan tingkat verticality konstruksi boiler yang ada di PLTU Desa Waai, Salahutu, Maluku Tengah, Maluku menggunakan data dari pengukuran TLS. Setelah itu, tingkat kelayakan bangunan tersebut ditentukan dengan membandingkan tingkat verticality yang diperoleh dengan stándar Queensland Building and Construction Admission Standards and Tolerances Guide tahun 2016.

\section{Data dan Metodologi}

\subsection{Data dan Lokasi}

Data berupa point cloud konstruksi boiler hasil pengukuran TLS pada bulan September 2016. Pengukuran dilakukan dengan TLS FARO Focus ${ }^{3 D}$ X330 dengan kerapatan point cloud (resolusi) $1 / 4$ dan quality scan $2 \mathrm{x}$. Pengukuran dilakukan di PLTU Desa Waai, Kecamatan Salahutu, Kabupaten Maluku Tengah. Lokasi PLTU ditunjukkan pada Gambar 2.1.

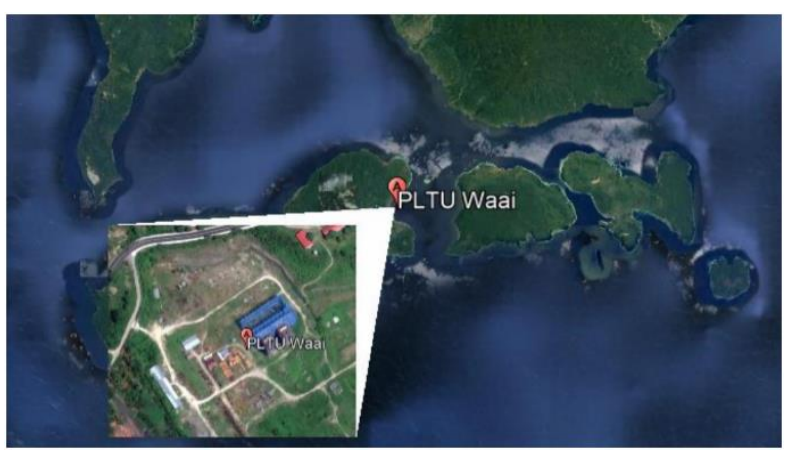

Gambar 2.1. Lokasi PLTU Waai Ambon

\subsection{Metodologi}

Verticality bangunan atau disebut pula plumbness (Victorian Building Commision, 2015) merupakan keadaan dimana titik puncak bangunan seharusnya memiliki koordinat $(\mathrm{x}, \mathrm{y})$ yang sama dengan titik pada pondasi yang ada di bawahnya. Penentuan verticality sangat penting untuk menentukan apakah bangunan perlu diperbaiki atau tidak (CD Surveys, 2015). Penentuan verticality bangunan boiler di PLTU ini dilakukan dalam beberapa tahap yaitu tahap pengukuran, registrasi data point cloud, ekstraksi garis dari point cloud, perhitungan verticality sampel, dan perbandingan hasil verticality dengan standar yang ada.

Pengukuran dilakukan dengan metode target based yang kemudain point cloud hasil pengukuran TLS yang terdiri atas beberapa scan world diregistrasi sehingga terbentuk objek konstruksi boiler yang utuh. Selanjutnya, proses ekstraksi garis dilakukan dalam Autodesk AutoCAD 2018. Dalam penentuan tingkat verticality dipilih beberapa sampel yang merupakan tiang utama yang ada pada konstruksi boiler. Contoh sampel tiang ditunjukkan pada Gambar 2.2.

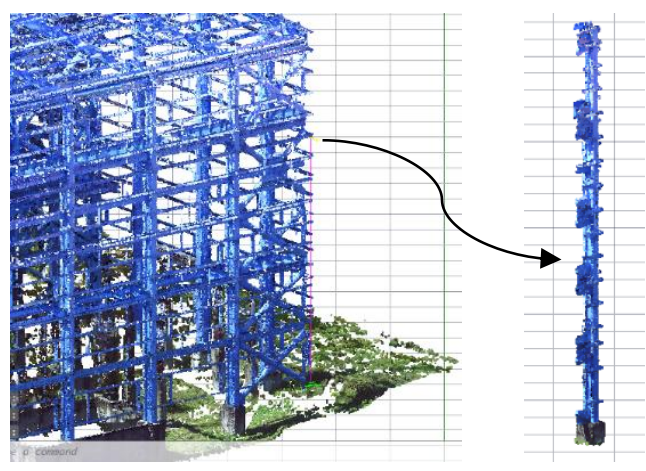

Gambar 2.2 Sampel tiang yang digunakan

Langkah selanjutnya yaitu ekstraksi titik ujung atas dan ujung bawah setiap sampel. Proses ekstraksi titik dimulai dengan memotong point cloud tiang secara horizontal dengan fitur section plane-top dengan section type slice. Selanjutnya, pembentukan segmen garis dilakukan dari hasil pemotongan point cloud dengan memasukkan beberapa parameter yaitu menentukan bagian point cloud yang akan diekstrak, geometri luaran yang diinginkan, jumlah maksimal titik pada point cloud yang diproses, serta toleransi ekstraksi (panjang garis minimal, toleransi jarak, dan toleransi sudut). Parameter-parameter tersebut merupakan parameter yang dibutuhkan untuk ekstraksi dengan metode Quality Error Metrics (QEM) (Hidaka, dkk, 2018). Setelah fitur garis terbentuk, kemudian menentukan titik ujung bawah dan ujung atas sampel yang merupakan titik perpotongan segmen garis yang terbentuk dari proses pembentukan segmen garis dari data point cloud.

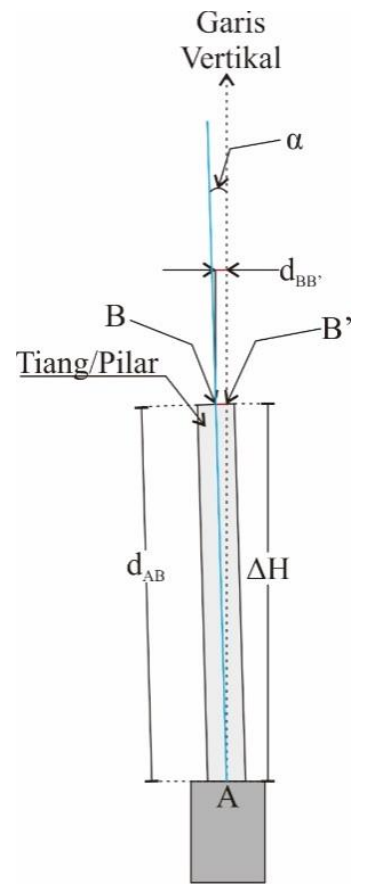

Gambar 2.3. Ilustrasi tingkat verticality (modifikasi Queensland Building and Construction Commission, 2016)

Keterangan Gambar 2.3:

A : titik ujung bawah tiang 
B : titik ujung atas tiang

B' : proyeksi titik ujung atas tiang terhadap garis vertikal

$\alpha \quad$ : sudut kemiringan tiang yang diuji

$\mathrm{d}_{\mathrm{AB}} \quad$ : panjang tiang

$\Delta \mathrm{H} \quad$ : beda tinggi titik ujung bawah dan ujung atas tiang

$\mathrm{d}_{\mathrm{BB}}$ : besar penyimpangan

Tingkat verticality dihitung dengan teorema Phytagoras untuk memperoleh sudut kemiringan tiang sampel. Tingkat verticality masing-masing sampel dihitung pada arah sumbu X, sumbu Y, dan resultan antara sumbu X dan sumbu Y. Tingkat verticality tiang diilustrasikan pada Gambar 2.3. dan sudut kemiringan $(\alpha)$ dihitung dengan rumus (1).

$$
\alpha=\tan ^{-1} \frac{d_{B B \prime}}{\Delta H}
$$

Besarnya penyimpangan ditentukan dengan nilai koordinat titik ujung bawah ( $\mathrm{X}_{\text {bawah, }} \mathrm{Y}_{\text {bawah, }} \mathrm{Z}_{\text {bawah }}$ ) dan koordinat titik ujung atas ( $\left.\mathrm{X}_{\text {atas, }}, \mathrm{Y}_{\text {atas, }} \mathrm{Z}_{\text {atas }}\right)$. Besarnya penyimpangan ada arah sumbu $\mathrm{X}\left(\mathrm{dBB}_{\mathrm{x}}{ }_{\mathrm{x}}\right)$, dihitung dengan rumus (2).

$$
d B B^{\prime}{ }_{x}=X_{\text {atas }}-X_{\text {bawah }}
$$

Besar penyimpangan pada arah sumbu $\mathrm{Y}\left(\mathrm{dBB}_{\mathrm{y}}^{\prime}\right)$, dihitung dengan rumus (3).

$$
d B B^{\prime}{ }_{y}=Y_{\text {atas }}-Y_{\text {bawah }}
$$

Penyimpangan pada resultan antara sumbu $\mathrm{X}$ dan sumbu Y ( $\left.\mathrm{dBB}_{\mathrm{xy}}\right)$, dihitung dengan rumus (4).

$$
d B B^{\prime}{ }_{x y}=\sqrt{\left(X_{\text {atas }}-X_{\text {bawah }}\right)^{2}+\left(Y_{\text {atas }}-Y_{\text {bawah }}\right)^{2}}
$$

Perhitungan besarnya sudut kemiringan yang menunjukkan tingkat verticality bangunan perlu ditentukan pula beda tinggi titik ujung bawah dan ujung atas $(\Delta \mathrm{H})$ yang dihitung dengan rumus $(5)$.

$$
\Delta H=Z_{\text {atas }}-Z_{\text {bawah }}
$$

Jika nilai penyimpangan dan beda tinggi yang ada pada rumus (1) disubstitusi dengan nilai pada rumus (2) dan (5), maka akan diperoleh rumus (6).

$$
\alpha=\tan ^{-1} \frac{X_{a t a s}-X_{\text {bawah }}}{Z_{\text {atas }}-Z_{\text {bawah }}}
$$

Jika penyimpangan dan beda tinggi pada rumus (1) disubstitusi dengan nilai pada rumus (3) dan (5) diperoleh rumus (7).

$$
\alpha=\tan ^{-1} \frac{Y_{\text {atas }}-Y_{\text {bawah }}}{Z_{\text {atas }}-Z_{\text {bawah }}}
$$

Jika besar penyimpangan dan beda tinggi pada rumus (1) disubstitusi dengan besar penyimpangan pada rumus (4) dan rumus (5) diperoleh rumus (8).

$$
\alpha=\tan ^{-1} \frac{\sqrt{\left(X_{\text {atas }}-X_{\text {bawah }}\right)^{2}+\left(Y_{\text {atas }}-Y_{\text {bawah }}\right)^{2}}}{Z_{\text {atas }}-Z_{\text {bawah }}}
$$

Hasil perhitungan tingkat verticality perlu dibandingkan dengan nilai toleransi verticality. Toleransi verticality mengacu standar Queensland Building and Construction Admission Standards and Tolerances Guide tahun 2016. Toleransi verticality yang diperbolehkan menurut standar tersebut tidak boleh lebih dari $20 \mathrm{~mm}$ jika dibandingkan dengan total ketinggian tiang, sehingga toleransi verticality dapat dihitung menggunakan rumus (1) dengan mensubstitusi nilai dBB' dengan nilai $20 \mathrm{~mm}$ baik pada arah sumbu $X$, sumbu $Y$, maupun resultan sumbu $X$ dan sumbu Y. Jika hasil perhitungan tingkat verticality sampel memiliki nilai yang lebih kecil jika dibandingkan dengan toleransi yang ada, maka sampel dikatakan tegak. Akan tetapi, jika hasil perhitungan tingkat verticality sampel memiliki nilai yang lebih besar dibandingkan toleransinya, maka sampel dikatakan miring.

\section{Hasil dan Pembahasan}

3.1. Hasil Ekstraksi Titik dan Hasil Tingkat Verticality

Proses ekstraksi titik bagian bawah dan bagian atas tiang menghasilkan beberapa informasi yaitu nilai koordinat ujung bawah dan ujung atas sampel. Daftar koordinat titik hasil ekstraksi ditunjukkan pada Tabel 3.1, sedangkan posisi sampel ditunjukkan pada Gambar 3.1.

Tabel 3.1 Koordinat titik uji ujung bawah dan ujung atas tiang

\begin{tabular}{ccccccc}
\hline \multirow{2}{*}{ No. } & \multicolumn{3}{c}{ Ujung Atas Tiang } & \multicolumn{3}{c}{ Ujung Bawah Tiang } \\
\cline { 2 - 7 } Tiang & Xb (m) & Yb (m) & Zb (m) & Xa (m) & Ya (m) & Za (m) \\
\hline 2 & 13,588 & 184,963 & 38,814 & 13,574 & 184,965 & 19,400 \\
4 & 19,930 & 177,024 & 39,000 & 19,915 & 177,020 & 19,400 \\
5 & 22,427 & 173,471 & 33,877 & 22,409 & 173,468 & 19,125 \\
6 & 22,475 & 172,024 & 41,413 & 22,474 & 172,040 & 19,375 \\
7 & 20,484 & 170,526 & 42,765 & 20,483 & 170,545 & 19,454 \\
8 & 23,916 & 166,061 & 44,287 & 23,924 & 166,077 & 19,487 \\
9 & 26,166 & 167,260 & 40,382 & 26,156 & 167,277 & 19,032 \\
11 & 30,105 & 163,655 & 42,595 & 30,091 & 163,653 & 19,468 \\
12 & 34,880 & 167,489 & 43,356 & 34,876 & 167,493 & 20,647 \\
15 & 49,128 & 178,452 & 43,731 & 49,119 & 178,459 & 19,400 \\
16 & 53,864 & 182,106 & 40,537 & 53,844 & 182,109 & 19,400 \\
19 & 68,132 & 193,129 & 42,688 & 68,115 & 193,128 & 19,250 \\
21 & 77,221 & 200,987 & 42,580 & 77,205 & 200,984 & 19,252 \\
22 & 80,013 & 202,270 & 42,750 & 79,995 & 202,277 & 19,450 \\
24 & 74,722 & 209,141 & 44,760 & 74,705 & 209,149 & 19,400 \\
26 & 70,258 & 214,940 & 45,907 & 70,241 & 214,949 & 19,250 \\
& 63,769 & 223,632 & 36,247 & 63,750 & 223,636 & 19,400
\end{tabular}




\begin{tabular}{|c|c|c|c|c|c|c|}
\hline 0 & 57,154 & 231,901 & 37,697 & 57,145 & 231,913 & 19,400 \\
\hline 32 & 50,002 & 226,423 & 38,946 & 49,991 & 226,436 & 19,400 \\
\hline 34 & 40,952 & 218,557 & 31,750 & 40,945 & 218,557 & 19,150 \\
\hline 37 & 26,685 & 207,571 & 34,354 & 26,675 & 207,565 & 19,150 \\
\hline 39 & 16,758 & 200,787 & 38,787 & 16,742 & 200,795 & 19,300 \\
\hline 41 & 7,672 & 192,919 & 33,982 & 7,665 & 192,934 & 19,300 \\
\hline 42 & 38,807 & 164,870 & 50,729 & 38,807 & 164,884 & 19,100 \\
\hline 45 & 50,778 & 174,491 & 50,641 & 50,767 & 174,492 & 19,400 \\
\hline 48 & 59,536 & 163,113 & 51,314 & 59,521 & 163,110 & 19,400 \\
\hline 51 & 46,968 & 153,444 & 53,287 & 46,982 & 153,455 & 19,256 \\
\hline 54 & 57,278 & 179,493 & 43,450 & 57,261 & 179,483 & 19,400 \\
\hline 57 & 69,737 & 188,704 & 46,500 & 69,721 & 188,712 & 19,250 \\
\hline 60 & 78,123 & 177,802 & 50,100 & 78,106 & 177,802 & 19,500 \\
\hline 63 & 66,079 & 168,545 & 53,100 & 66,083 & 168,538 & 19,400 \\
\hline
\end{tabular}

Koordinat pada Tabel 3.1 menunjukkan posisi sampel yang digunakan untuk melakukan perhitungan tingkat verticality. Secara visual, koordinat tiang-tiang yang digunakan sebagai sampel dapat digambarkan pada Gambar 3.1.

Tingkat verticality diperoleh dari selisih koordinat hasil ekstraksi titik bagian atas dan bagian bawah sampel. Selisih koordinat dihitung pada arah sumbu X dan sumbu Y. Selisih koordinat (penyimpangan) masing-masing tiang pada arah sumbu $X$ berkisar antara $-1,4$ hingga $1,9 \mathrm{~cm}$ dengan mayoritas mengarah ke arah sumbu-X positif. Penyimpangan masing-masing tiang pada arah sumbu $Y$ berkisar antara $-1,9$ hingga $1,0 \mathrm{~cm}$ dengan mayoritas mengarah ke arah sumbu-Y negatif. Setelah diperoleh selisih koordinat masing-masing tiang, selanjutnya dihitung nilai resultan dari kedua sumbu tersebut dan diperoleh penyimpangan yang berkisar antara $0,55 \mathrm{~cm}$ hingga $1,96 \mathrm{~cm}$. Selain diperoleh penyimpangan pada arah sumbu $\mathrm{X}$, sumbu $\mathrm{Y}$, dan resultannya, diperoleh pula tinggi masing-masing sampel tiang yang berkisar antara 12,600 hingga 34,032 meter.

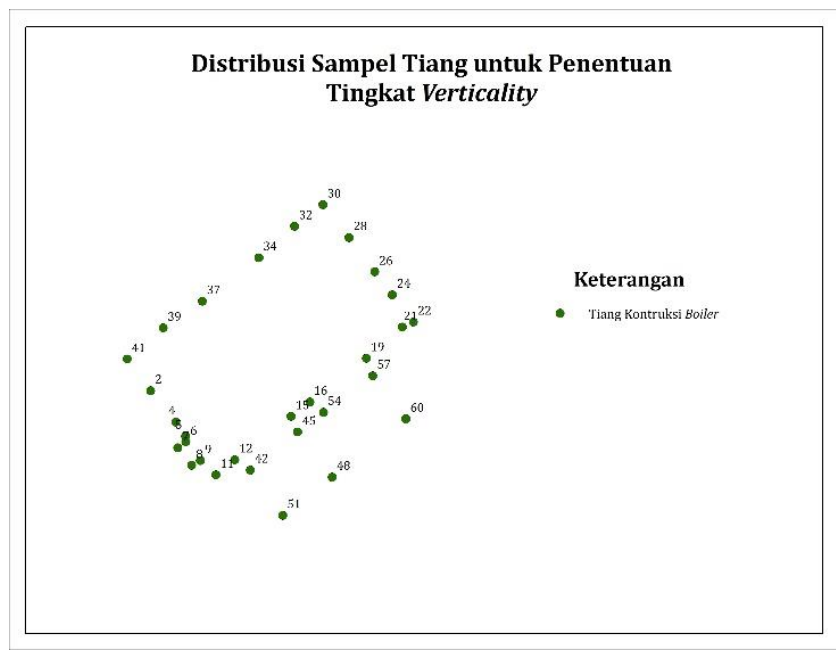

Gambar 3.1. Posisi sampel tiang

Berdasarkan besarnya penyimpangan dan beda tinggi yang diperoleh, kemudian dilakukan perhitungan tingkat verticality menggunakan rumus 6 , rumus 7 , dan rumus 8 sehingga diperoleh tingkat verticality pada arah sumbu $\mathrm{X}$, sumbu Y, dan resultannya. Tingkat verticality pada arah sumbu X ditunjukkan pada Gambar 3.2.

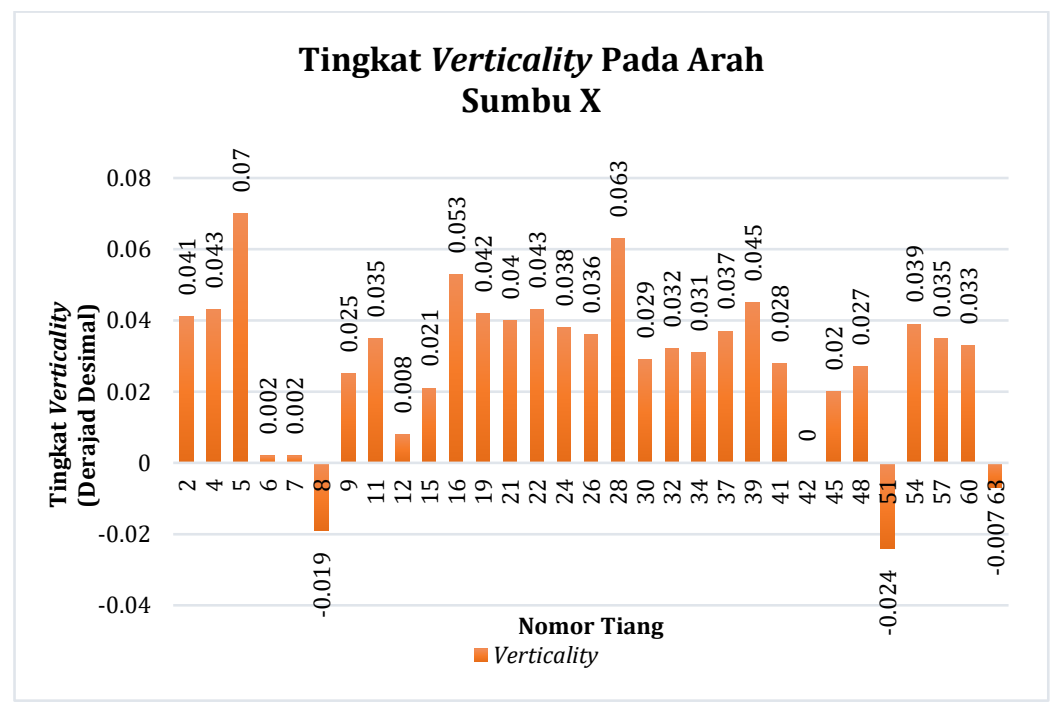

Gambar 3.2. Grafik tingkat verticality pada arah sumbu X

Berdasarkan Gambar 3.2. dapat diperoleh tingkat verticality terhadap sumbu X berkisar antara $-0^{\circ} 1^{\prime} 26,678^{\prime \prime}$ hingga $0^{\circ}$ 4' 11,778". Arah penyimpangan mayoritas mengarah ke sumbu X positif dengan jumlah 28 tiang. Tingkat verticality pada arah sumbu Y ditunjukkan pada Gambar 3.3. 


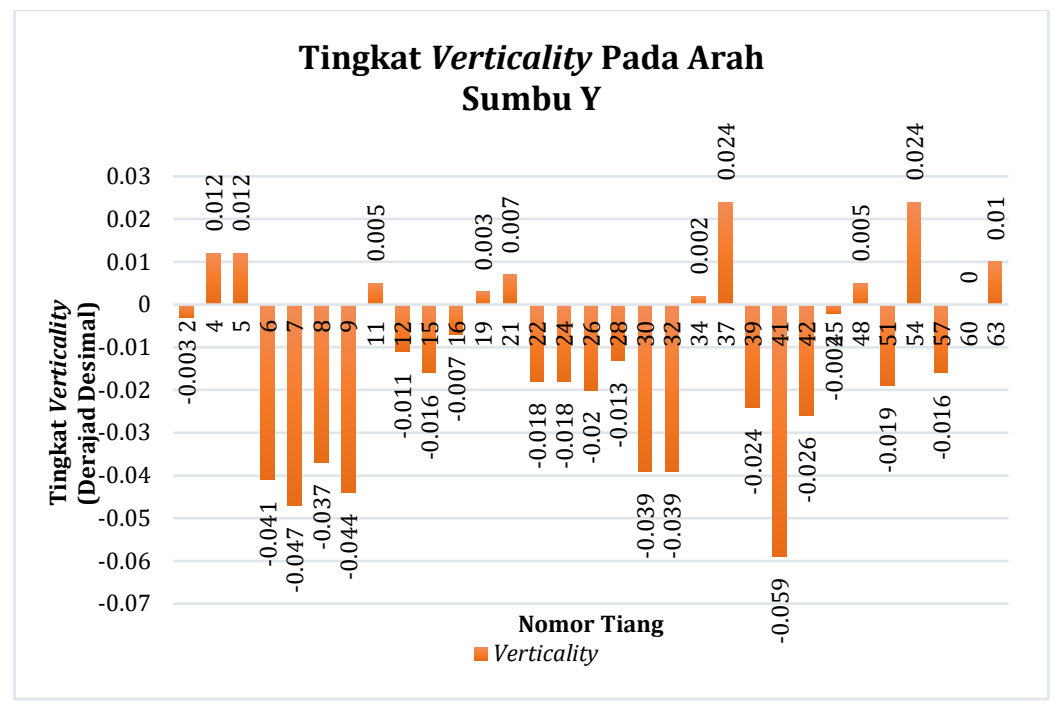

Gambar 3.3. Grafik tingkat verticality pada arah sumbu Y

Berdasarkan Gambar 6, tingkat verticality pada arah sumbu Y berkisar antara $-0^{\circ} 3^{\prime} 33,345^{\prime \prime}$ hingga $0^{\circ} 1^{\prime}$ 25,319". Mayoritas sampel mengarah ke arah sumbu Y negatif yaitu berjumlah 21 tiang. Tingkat verticality resultan sumbu X dan sumbu Y ditunjukkan pada Gambar 3.4.

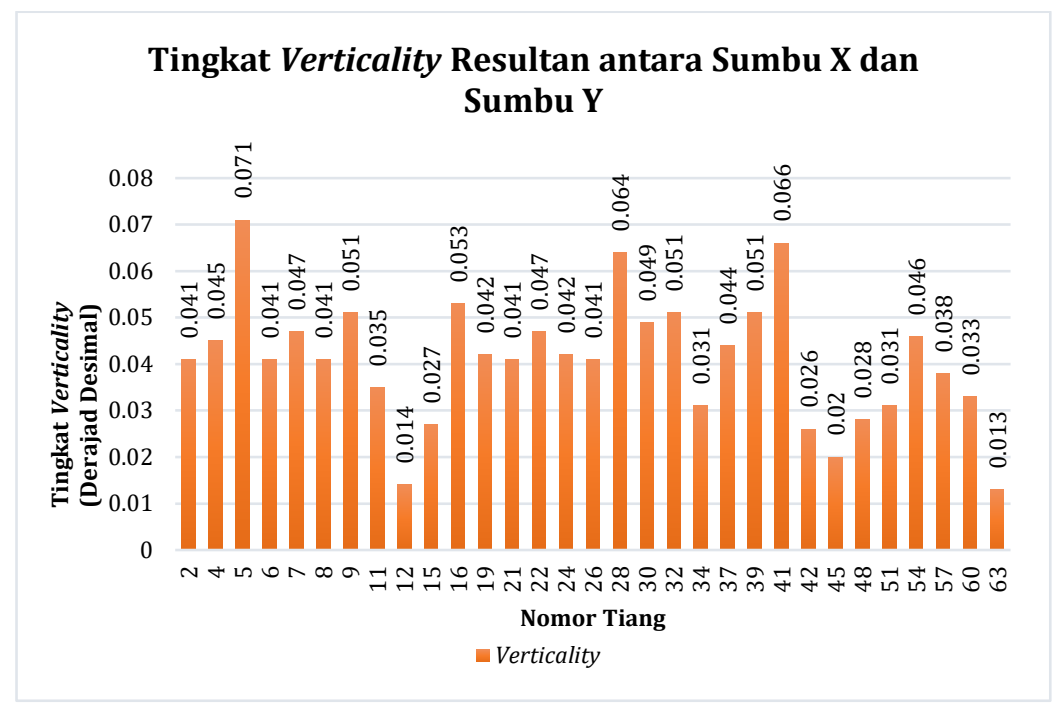

Gambar 3.4. Grafik tingkat verticality resultan antara sumbu-X dan sumbu-Y

Berdasarkan Gambar 3.4. dapat diketahui bahwa tingkat verticality dari resultan antara sumbu X dan sumbu Y berkisar antara $0^{\circ} 0^{\prime} 45,225^{\prime \prime}$ hingga $0^{\circ} 4^{\prime} 15,674$ ". Berdasarkan ke-31 sampel tiang yang digunakan terdapat 19 tiang dengan penyimpangan mengarah ke arah Tenggara, 2 tiang ke arah Barat Daya, 1 tiang mengarah ke arah Barat Laut, dan 9 tiang mengarah ke arah Timur Laut. Berdasarkan hasil tersebut, maka mayoritas sampel yang digunakan menyimpang ke arah Tenggara.

\subsection{Hasil Uji Tingkat Verticality}

Pengujian tingkat verticality dilakukan dengan membandingkan hasil perhitungan tingkat verticality masing-masing sampel dengan nilai toleransinya. Menurut standar yang diterbitkan oleh Queensland Building and Construction Commission (2016), dijelaskan bahwa untuk suatu tiang dalam 12 bulan pertama sejak selesai dibangun dikatakan tidak vertikal apabila mengalami penyimpangan dari garis vertikal sebesar lebih dari 20 mm untuk total ketinggian tiang. Toleransi tingkat verticality dihitung menggunakan rumus 1 dengan mensubtitusikan nilai $\mathrm{d}_{\mathrm{BB}^{\prime}}$ dengan nilai toleransi verticality yaitu $20 \mathrm{~mm}(0,020 \mathrm{~m})$

Masing-masing tiang memiliki toleransi yang berbeda. Hal tersebut dikarenakan beda tinggi setiap titik ujung bawah dan titik ujung atas masing-masing tiang sampel memiliki nilai yang berbeda. Nilai beda tinggi tersebut 
merupakan salah satu parameter yang digunakan dalam perhitungan toleransi tingkat verticality dari suatu tiang. Pengujian tingkat verticality dilakukan pada arah sumbu X, pada arah sumbu $\mathrm{Y}$, dan resultan antara sumbu $\mathrm{X}$ dan sumbu Y.

Pada ilustrasi perbandingan antara tingkat verticality dan toleransi dalam satu grafik, tingkat verticality perlu diabsolutkan terlebih dahulu karena nilai toleransi verticality selalu bernilai positif dapat dilihat pada Gambar 3.5. s.d. 3.7. Grafik perbandingan antara tingkat verticality dengan toleransi pada arah sumbu X ditunjukkan pada Gambar 3.5.

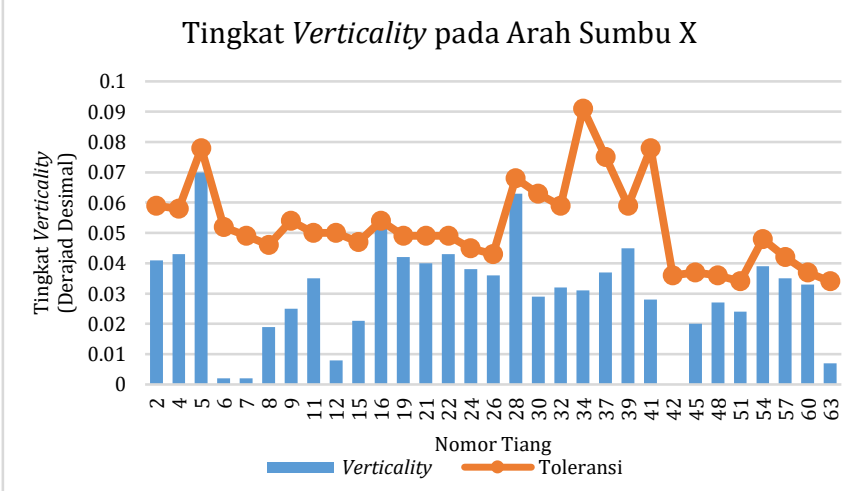

Gambar 3.5 Grafik perbandingan tingkat verticality dan toleransinya pada arah sumbu X

Berdasarkan Gambar 3.5, dapat diketahui bahwa tingkat verticality masing-masing sampel tiang yang digunakan memiliki nilai yang lebih kecil jika dibandingkan dengan toleransinya. Hal tersebut ditunjukkan dengan tingkat verticality masing-masing sampel berada di bawah garis toleransinya. Grafik tingkat verticality dan toleransi pada arah sumbu Y ditunjukkan pada Gambar 3.6.

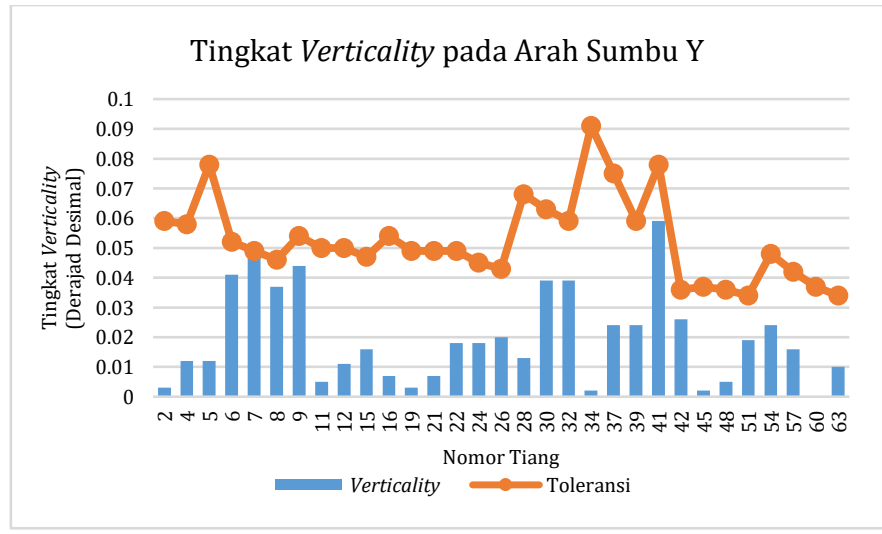

Gambar 3.6. Grafik perbandingan tingkat verticality dan toleransinya pada arah sumbu Y

Gambar 3.6. menunjukkan tingkat verticality sampel tiang pada arah sumbu Y berada di bawah nilai toleransi masing-masing sampel. Oleh karena itu, dapat dikatakan bahwa nilai tingkat verticality masing-masing sampel pada arah sumbu Y lebih kecil dibandingkan dengan toleransinya. Grafik perbandingan tingkat verticality dan toleransi pada resultan antara sumbu $\mathrm{X}$ dan sumbu $\mathrm{Y}$ ditunjukkan pada Gambar 3.7.

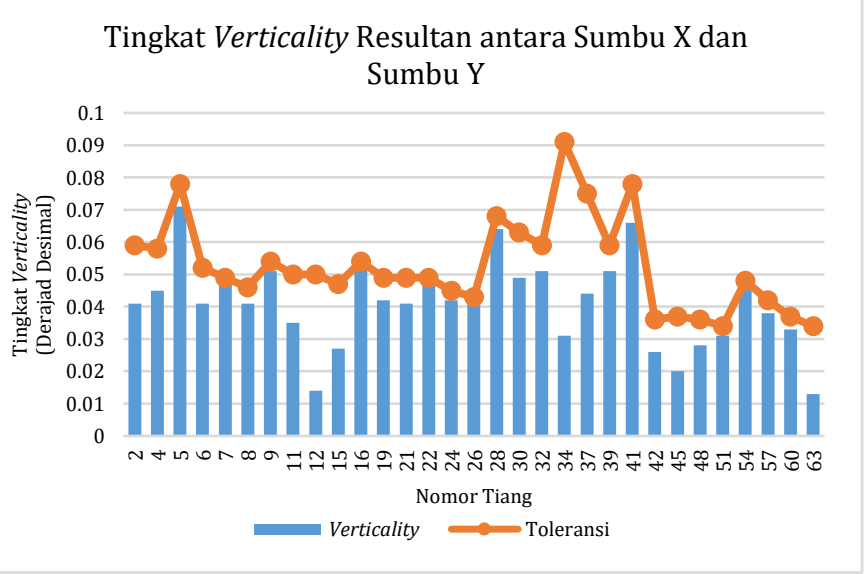

Gambar 3.7. Grafik perbandingan tingkat verticality dan toleransinya pada resultan antara sumbu X dan sumbu $Y$

Gambar 3.7. menunjukkan bahwa keseluruhan sampel yang digunakan memiliki tingkat verticality yang lebih kecil dibandingkan dengan toleransinya pada resultan antara sumbu X dan sumbu Y. Hal tersebut ditunjukkan dengan tingkat verticality keseluruhan sampel yang digunakan berada dibawah garis toleransinya.

Berdasarkan ketiga grafik tersebut, diperoleh tingkat verticality yang bernilai lebih kecil daripada toleransinya baik pada arah sumbu X, sumbu Y, maupun pada resultan antara sumbu $X$ dan sumbu $Y$. Hal tersebut mengindikasikan bahwa tingkat verticality masing-masing tiang masih dalam toleransi. Untuk mengetahui kelayakan suatu bangunan diperlukan pengujian kekuatan pondasi dan tingkat verticality. Berdasarkan hasil yang diperoleh dari kajian ini, dari sisi tingkat verticality bangunan boiler di PLTU Waai Ambon masih berada dalam batas toleransi, hal tersebut mengindikasikan bahwa salah satu syarat kelayakan bangunan telah terpenuhi dan masih sangat mungkin untuk dilanjutkan pembangunannya tanpa harus melakukan pembangunan ulang.

Tingkat verticality yang bervariasi disebabkan karena tinggi masing-masing sampel tiang yang diuji berbedabeda. Tinggi sampel tiang yang berbeda juga mempengaruhi besarnya toleransi verticality untuk masing-masing tiang. Semakin tinggi tiang, risiko bangunan mengalami kemiringan akan lebih tinggi dan toleransinya akan semakin ketat. Selain itu, jika dilihat dari arah kemiringan resultan sumbu $\mathrm{X}$ dan sumbu $\mathrm{Y}$ mayoritas mengarah ke arah tenggara. Informasi arah kemiringan tersebut berguna untuk mengantisipasi terjadinya kemiringan ke arah yang sama, sehingga perlu dilakukan perkuatan pada bangunan untuk mengurangi besar kemiringan ke arah tersebut agar bangunan boiler tetap dapat dilanjutkan pembangunannya.

\section{Kesimpulan}

Kesimpulan hasil kajian ini sebagai berikut:

a. Tingkat verticality pada 31 sampel memiliki nilai yang bervariasi. Tingkat verticality pada arah sumbu X 
mayoritas menuju ke arah sumbu $\mathrm{X}$ positif. Tingkat verticality pada arah sumbu Y mayoritas menuju ke arah sumbu $\mathrm{Y}$ negatif. Pada resultan antara sumbu $\mathrm{X}$ dan sumbu $Y$ diperoleh nilai tingkat verticality antara $0^{\circ} 0^{\prime} 45,225^{\prime \prime}$ hingga $0^{\circ} 4^{\prime} 15,674^{\prime \prime}$, dengan rata-rata tingkat verticality sebesar $0^{\circ} 2^{\prime} 27,057^{\prime \prime}$ pada semua tiang yang diuji.

b. Tingkat verticality yang diperoleh dari hasil pengukuran TLS tersebut memiliki nilai yang lebih kecil jika dibandingkan dengan toleransi yang ada pada standar Queensland Building and Construction Admission Standards and Tolerances Guide tahun 2016 pada semua tiang yang diuji. Oleh karena itu, konstruksi bangunan boiler yang ada di Desa Waai, Kecamatan Salahutu, Kabupaten Maluku Tengah, Provinsi Maluku masih memenuhi persyaratan untuk dapat dilanjutkan pembangunannya tanpa harus membangun ulang konstruksi bangunan boiler tersebut.

\section{Pernyataan Konflik Kepentingan}

Penulis menyatakan tidak ada konflik kepentingan dalam artikel ini (The authors declare no competing interest).

\section{Referensi}

Biro Perencanaan dan Kerja Sama Mineral Kementerian Energi dan Sumber Daya (2015) Rencana Strategis Kementerian Energi dan Sumber Daya Mineral 20152019. Jakarta: Kementrian ESDM.

CD Surveys (2015) Site Engineering Services. Available at: http://www.cdsurveys.com/site-engineering-services.

Genchten, B. Van (2008) Theory and Practice on Terrestrial Laser Scanning, Learning Tools for Advanced Threedimensional Surveying in Risk Awareness Project. doi: 978-84-8363-312-0.

Hidaka, N., Michikawa, T., Motamedi, A., Yabuki, N., dan Fukuda, T (2018) 'Polygonization of point clouds of repetitive components in civil infrastructure based on geometric similarities', Automation in Construction, 86(November 2017), pp. 99-117. doi: 10.1016/j.autcon.2017.10.014.

Kregar, K. Ambrožič, T., Kogoj, D., Vezočnik, R., dan Majertič, A. (2015) 'Determining the inclination of tall chimneys using the TPS and TLS approach', Measurement: Journal of the International Measurement Confederation, 75, pp. 354-363. doi: 10.1016/j.measurement.2015.08.006.

Queensland Building and Construction Commission (2016) Standards and Tolerances Guide. Available at: https://www.qbcc.qld.gov.au/sites/default/files/Stan dards_and_Tolerances_Guide_0.pdf.

Soudarissanane, S. (2016) The Geometry of Terrestrial Laser Scanning: Identification of Errors, Modeling and Mitigation of Scanning Geometry.

Victorian Building Commision (2015) Guide to Standards and Tolerance 